УДК 342.9

DOI https://doi.org/10.32782/2524-0374/2020-4/30

\title{
THE GROUNDS OF THE INTEGRITY TEST OF EMPLOYEES OF THE NATIONAL ANTI-CORRUPTION BUREAU OF UKRAINE
}

\section{ПІДСТАВА ПЕРЕВІРКИ НА ДОБРОЧЕСНІСТЬ ПРАЦІВНИКІВ НАЦІОНАЛЬНОГО АНТИКОРУПЦЙНОГО БЮРО УКРАЇНИ}

\author{
Braverman O.O., Postgraduate Student \\ at the Department of Public Administration and Management \\ National Academy of Internal Affairs, \\ Senior Detective at the Devision of Internal Investigation \\ of the Department of Internal Control \\ National Anti-Corruption Bureau of Ukraine
}

The purpose of this article - to determine the legal and factual grounds for the integrity test of employees of the National Anti-Corruption Bureau of Ukraine.

The work is performed by applying general research and special methods of scientific knowledge. With the help of methods of abstraction, analysis and synthesis of the author by rejecting the insignificant properties of the integrity test at the same time managed to identify the grounds of this phenomenon. Dialectical and logical methods allowed to clarify the essence of factual and legal grounds for the integrity test, to specify the list of concepts. Using forecasting and modeling, the author is proposed a specific model of legal regulation of the grounds for the integrity test of employees of the National Anti-Corruption Bureau of Ukraine.

In the article the legal (regulatory) and factual (material) grounds for the integrity test of employees of the National Bureau are examined. It's established that the legal (regulatory) grounds is, in fact, the legislative permission for the integrity test. The definition of the factual (material) basis for the test as a certain legal fact, with the onset of which there is a need for an integrity test by the Department of Internal Control of the National Bureau is proposed.

In the course of scientific research it was established that at present there is no proper legal grounds for conducting the integrity test of employees of the National Bureau, as the legal grounds for conducting the integrity test in the National Bureau are defined in an internal document. At the same time, the author has improved the factual grounds for conducting the integrity test.

Key words: the integrity test, public service, administrative control, simulation of situations, non-integrity behavior.

Статтю присвячено висвітленню юридичних та фактичних підстав для проведення перевірки на доброчесність працівників Національного антикорупційного бюро України.

Дане дослідження виконано шляхом застосування загальних та спеціальних методів наукового пізнання. За допомогою методів абстрагування, аналізу та синтезу автору шляхом відкидання незначних властивостей перевірки на доброчесність одночасно вдалося виявити підстави цього явища. Діалектичний та логічний методи дали змог уточнити сутність фактичних та юридичних підстав перевірки на доброчесність, уточнити перелік понять. Використовуючи прогнозування та моделювання, автором запропоновано конкретну модель правового регулювання підстав для проведення перевірки на доброчесності працівників Національного антикорупційного бюро України.

У статті розглянуто юридичні (нормативні) та фактичні (матеріальні) підстави для проведення перевірки на доброчесність працівників Національного бюро. Встановлено, що юридичні (нормативні) підстави, по суті, є законодавчим дозволом на проведення перевірки на доброчесність та визначають, хто суб'єкт та об'єкт такої перевірки, їхні права та обов'язки в ході її проведення тощо.

Під фактичними (матеріальними) підставами для перевірки на доброчесність запропоновано розуміти певний юридичний факт, із настанням якого виникає необхідність проведення перевірки на доброчесність Управлінням внутрішнього контролю Національного бюро. Однак сьогодні фактична (матеріальна) підстава для проведення перевірки на доброчесність законодавчо не встановлена.

У ході наукового дослідження встановлено, що нині відсутні належні правові підстави для проведення перевірки на доброчесність працівників Національного бюро, оскільки останні визначені у внутрішньому документі, а саме Положенні про Управління внутрішнього контролю Національного антикорупційного бюро України, затвердженому Наказом Директора Національного антикорупційного бюро України від 29.11.2019 № 142 [3]

Автором також зауважено, що такі суттєві обмеження прав і свобод людини, яких зазнає працівник Національного антикорупційного бюро України під час проведення перевірки на доброчесність, мають бути обов'язково врегульовані в нормативно-правовому акті. Недопустимо, щоб указаний засіб утручання в особисте життя, підстави, порядок його застосування та межі визначалися виключно внутрішньовідомчими документами.

За результатами виконання поставлених науково-дослідницьких завдань автором виокремлено юридичні та фактичні підстави для проведення перевірки на доброчесність працівників Національного бюро, запропоновано їх доповнення та нормативне вдосконалення.

Ключові слова: перевірка на доброчесність, державна служба, адміністративний контроль, моделювання ситуації, недоброчесна поведінка.

Recent events in the country show that every measure of implemented by law enforcement agencies or the power bloc, as a result of which significant interference with human and civil rights and freedoms or their significant or long-term restriction must require clear regulation and consolidation. As the case law of the European Court of Human Rights shows, this is a priority issue that becomes the subject of litigation and research: whether legal and factual grounds were for taking this or that measure, whether the official authority was exceeded during the choosing of this or that form of reaction.

In total, during the functioning of the Department of Internal Control conducted 53 the integrity test of employees of the National Anti-Corruption Bureau of Ukraine, 3 of them were negative $(5.6 \%$ of the total number of tests) [1]
These statistics indicate the grounds and procedure for conducting the integrity test by the Department of Internal Control of the National Bureau are need to improve.

However, at present, the integrity tetst of employees of the National Anti-Corruption Bureau of Ukraine has not been the subject of research by either domestic or foreign scientists due to the specifics of the subject of the research.

The purpose of this article is to determine the legal and factual grounds for the integrity test of employees of the National Anti-Corruption Bureau of Ukraine, to formulate the stages of this procedure.

The work is performed by applying general research and special methods of scientific knowledge. With the help of methods of abstraction, analysis and synthesis of the author by rejecting the insignificant properties of the integrity test 
at the same time managed to identify the grounds and stages of implementation of this phenomenon. Dialectical and logical methods allowed to clarify the essence of factual and legal grounds for the integrity test, to specify the list of concepts. Using forecasting and modeling, the author is proposed a specific model of legal regulation of the grounds and procedure for the integrity test of employees of the National Anti-Corruption Bureau of Ukraine.

The research tasks of this article are: 1) to examine the legal (regulatory) and factual (material) grounds for the integrity test of employees of the National Bureau; 2) to define the procedure for the integrity test of employees of the National Bureau and to analyze stages of it.

The legal (regulatory) ground answers to the question whether the legislator allows the integrity test in general, who is the subject and object of such test, their rights and responsibilities during its conduct, etc.

At the same time, the integrity test is only mentioned in the Law of Ukraine "On the National Anti-Corruption Bureau of Ukraine" [2], however, it's not clearly regulated, the definition of integrity, the integrity test, the procedure of integrity test and its components are not defined.

In particular, Part 2 of Art. 13 of the Law stipulates that when appointed to a position in the National Bureau, a person is informed about the possibility of conducting a integrity test and monitoring of the lifestyle.

Paragraph 3 of Part 2 of Art. 27 of this legal act stipulates that the internal control unit of the National Bureau has, in particular, the obligation to conduct inspections of employees of the National Bureau for integrity and monitoring of their lifestyle.

At the same time, the legal grounds for conducting the integrity test in the National Bureau are not set out in a separate internal document, but in Section VII of the Regulations on the Department of Internal Control of the National Anti-Corruption Bureau of Ukraine, approved by the National Bureau Director's Order of November 29, 2019 № 142 [3]. But it allows full discretion of the Director of the National Anti-Corruption Bureau of Ukraine and the head of the internal control unit in determining the procedure of the integrity test, its grounds, arbitrary change and determination of these legal instruments of administrative control by the employer, which is excessive interference with the rights and freedoms of employees of the National Bureau, this violates the principle of legal certainty.

Therefore, in our opinion, there is currently no proper legal basis for the application of the integrity test by the National Anti-Corruption Bureau of Ukraine.

In view of the above, it should be noted that such significant restrictions on human rights and freedoms that an employee of the National Anti-Corruption Bureau of Ukraine experiences during the integrity test, in our opinion, must be regulated in a legal act. It is inadmissible that the specified means of interference in private life, the grounds, the order of its application and the limits are determined exclusively by internal documents.

As for the factual (material) basis for the test, in our opinion, it should be understood as a certain legal fact, with the onset of which there is a need for conducting the integrity test by the Department of Internal Control of the National Bureau.

The law does not establish the factual (material) basis for conducting the integrity test.

After analyzing the provisions of Part 2 of Art. 13 of the Law of Ukraine "On the National Anti-Corruption Bureau of Ukraine" [2], according to which when appointed to a position in the National Bureau a person is notified of the possibility of conducting the integrity test and lifestyle monitoring, and provisions of Section VII of the Regulations on the Department of Internal Control of the National Anti-Corruption Bureau of Ukraine [3] that the simulation of the situation is carried out with the permission of the Head of the Department of Internal Control on the basis of a memorandum of an employee of the Department, who received information indicating the possibility of non-integrity behavior of an employee of the National Bureau, the following factual (material) grounds for the integrity test should be identified: 1) notification of the employee of the National Bureau upon appointment to the position on the possibility of conducting the integrity test on him; 2) receipt by the employee of the Department of Internal Control of the National Bureau of information indicating the possibility of non-integrity behavior of the employee of the National Bureau; 3) permission of the Head of the Department of Internal Control for such test.

In order to understand whether there is such a factual (material) ground for conducting the integrity test as a notification of an employee of the National Bureau when appointing to the position about the possibility of conducting such a test on him, one should pay attention to two points. Thus, the specified notification, in our opinion, should be in writing with the corresponding mark of the newly appointed person on acquaintance with the content of such notification.

The second point to pay attention to is the time limit of such notification, namely when appointing. In our opinion, it would be a logical legislative continuation, and in case of refusal to get acquainted with the signature with the notification about the possibility of conducting the integrity test, this employee cannot be appointed to the position.

There are also uncertain legal consequences if an employee of the National Bureau is informed about the possibility of conducting the integrity test against him not at the time of appointment, but after the appointment. In our opinion, such points need legislative regulation.

Consider the following factual (material) ground for conducting the integrity test, namely the receipt of information by an employee of the Department of Internal Control of the National Bureau, which indicates the possibility of nonintegrity behavior of an employee of the National Bureau.

However, it should be noted that this wording does not preclude arbitrariness on the part of employees of the Department of Internal Control, who, guided by hostile relations with certain employees of the National Bureau, who may have formed in the performance of other duties, indicate knowingly false information in such memorandum the possibility of non-integrity behavior of a particular employee.

In view of the above, it is appropriate, in our opinion, the ground for the integrity test of employees of the National Bureau to determine information about the possibility of nonintegrity behavior of a particular employee of the National Bureau, received by the Department of Internal Control by phone, mail, e-mail address, is found during an official investigation, pre-trial investigation or criminal intelligence and is executed by a relevant memorandum with supporting documents. That is, in case of need or doubt in the impartiality of the relevant employee of the internal control unit of the National Bureau, it is possible to check the reality of such information and prevent abuse of rights by employees of the Department.

The next factual (material) ground for conducting the integrity test is the permission of the Head of the Department of Internal Control for such test.

However, it should be noted that currently neither the laws of Ukraine "On the National Anti-Corruption Bureau of Ukraine" [2], "On Civil Service" [4], nor internal documents of the National Bureau regulate such a form of administrative document as a permit.

In this regard, in our opinion, it would be more appropriate to phrase that the Head of the Department of Internal Control provides a written proxy in the form of a resolution to conduct the integrity test, which in turn is consistent with the provisions of paragraph 27 of the Instructions on Paperwork Management in the National Anti-Corruption Bureau of Ukraine, 
approved by the order of the Director of the National Bureau February 19, 2019 № 26 [5].

It is also impossible not to pay attention to the presence of corruption risk and possible abuse by the head of the internal control unit of the National Bureau, who has the right not to grant such permission, even if there are reasonable grounds for the integrity test of a particular employee of the National Bureau. However, there is no mechanism for appealing this decision, as well as external control to ensure the objectivity and impartiality of the exercise of such discretionary powers.

In view of the above, in our opinion, the employees of the Department of Internal Control should be given the opportunity to appeal both the issuance of a permit and the refusal to issue a permit for the integrity test to the Director of the National Bureau, who would make a final decision, which based on the results of acquaintance and analysis of the materials collected by the complainant.

Thus, it should be noted that the Department of Internal Control of the National Bureau is a pioneer in Ukraine of conducting the integrity test in classic "New York" sense [6]. At the same time, the grounds for the integrity test need more balanced legislation and further improvement in order to make more effective use of this tool in the field of anti-corruption among employees of the National Bureau.

\section{REFERENCES}

1. Звіти про роботу Національного антикорупційного бюро за 2015-2019 роки. URL : https://nabu.gov.ua/reports (дата звернення: 07.07.2020).

2. Про Національне антикорупційне бюро України : Закон України № 1698-VII від 14.10.2014. URL : https://zakon.rada.gov.ua/laws/ show/1698-18 (дата звернення: 07.07.2020).

3. Положення про Управління внутрішнього контролю Національного антикорупційного бюро України : Наказ Директора Національного антикорупційного бюро України від 29.11.2019 № 142. URL : https://nabu.gov.ua/sites/default/files/page_uploads/02.12/ nakaz_uvk.pdf (дата звернення: 07.07.2020).

4. Про державну службу : Закон України № 889-VIII від 10.12.2015. URL : https://zakon.rada.gov.ua/laws/show/889-19\#Text (дата звернення: 07.07.2020).

5. Інструкція з діловодства у Національному антикорупційному бюро України : Наказ Директора Національного бюро від 19.02.2019 № 26. URL : https://nabu.gov.ua/sites/default/files/page_uploads/25.02/26_nakaz.pdf (дата звернення: 07.07.2020).

6. Narelle Willingham. 2014. To Undertake Specialized Training in Integrity Testing. Canberra: The Winston Churchill Memorial Trust of Australia. URL : https://www.churchilltrust.com.au/media/fellows/To_undertake_specialised_training_in_integrity_testing_N_Beer_2013.pdf (дата звернення: 07.07.2020). 